\title{
Penggunaan Radio Frequency Identification dalam Proses Absensi Kehadiran Pegawai Menggunakan Arduino
}

\author{
Frisman Panjaitan ${ }^{* 1}$, Solikhun ${ }^{2}, Z_{\text {Zulaini Masruro Nasution }}^{3}$, Sumarno ${ }^{4}$, Indra Gunawan ${ }^{5}$ \\ 1,2,3,4,5 Teknik Informatika, STIKOM Tunas Bangsa Pematangsiantar, Indonesia \\ Email: ${ }^{1}$ panjaitanf955@gmail.com, ${ }^{2}$ Solikhun@amiktunasbangsa.ac.id, \\ ${ }^{3}$ zulen_nasution04@ymail.com, ${ }^{4}$ sumarno@amiktunasbangsa.ac.id, ${ }^{5}$ indra@ amiktunasbangsa.ac.id
}

\begin{abstract}
Abstrak
Di era saat ini masih banyak perkantoran yang menggunakan pencatatan manual dalam system absensi pegawainya, yaitu dengan mencatat kehadiran saat hadir maupun saat selesai watu pekerjaan, hal itu di rasa sangat memakan waktu dan mengurangi tingkat efesiensi dan keakurasian dalam pengoptimalam kinerja. Berdasarkan hal tersebut penulis merancang sebuah prototype system absensi pegawai menggunakan Radio Frequency Identification berbasis mikrokontroller Arduino, dimana sistem ini absensi yang menggunakan Radio Frequency Identification ini terintegrasi dengan database, sehingga dapat mudah di monitor dan di awasi dalam proses absensi kepegawaian.
\end{abstract}

Kata kunci: Absensi Otomatis, Arduino, RFID

\section{Abstract}

In the current era, there are still many offices that use manual recording in their employee attendance system, namely by recording attendance when attending or when work is finished, it is considered very time consuming and reduces the level of efficiency and accuracy in optimizing performance. Based on this, the authors designed a prototype employee attendance system using Radio Frequency Identification based on an Arduino microcontroller, where this attendance system that uses Radio Frequency Identification is integrated with the database, so that it can be easily monitored and supervised in the employee attendance process.

Keywords: Arduino, Automatic Attendance, RFID

\section{PENDAHULUAN}

Perkembangan teknologi sangat cepat. Segala upaya dilakukan untuk mempermudah pekerjaan manusia dari waktu kewaktu yang membutuhkan mobilitas tinggi dalam melakukan pekerjaannya serta otomatisasi sehingga manusia mendapat kemudahan dari teknologi.

Absensi kehadiran pegawai, sehingga mengakibatkan seringnya terjadi manipulasi data kehadiran. Alat absensi ini sangat diperlukan, di tempat intansi kantor camat Kabupaten Simalungun absensi nya masih menggunakan pencatatan kehadiran manual sehingga membutuhkan banyak kertas, tinta dan membutuhkan ruang yang besar untuk tempat menyimpan data presensi. Selain itu tidak bisa membantu waktu kehadiran pegawai secara rinci.

Sistem absensi manual sangat tidak praktis dalam proses perekapan absensi ke server pusat, karena harus dilakukan secara manual dan terdapat kemungkinan terjadi kesalahan dalam proses perekapannya yang disebabkan human error. Data absensi diserver tidak dapat langsung diupdate, Oleh karna itu dibutuhkan sistem absensi yang teritegrasi agar dapat meminimalisir kesalahan-kesalahan tersebut.

RFID (Radio Frequency Identification) adalah teknologi identifikasi berbasis gelombang). Metode identifikasinya menggunakan sarana yang disebut label RFID atau transponder (tag) untuk menyimpan dan mengambil data jarak jauh. Teknologi ini mampu mengidentifikasi berbagai objek secara simultan tanpa diperlukan kontak langsung (atau dalam jarak pendek). Implementasi RFID secaraefektif digunakan pada lingkungan manufaktur atau industri yang memerlukan akurasi dan kecepatan identifikasi objek dalam jumlah yang besar serta berbeda di area yang luas. 
Namun kini RFID tidak hanya terbatas namun sudah merambah pada banyak bidang lain, diantaranya sebagai salah satu teknologi informasi yang memudahkan manusia untuk identifikasi berbagai hal secara otomatis.

Pada penelitian ini, penulis merancang Penggunaan RFID (Radio Frequency Identification) dalam proses absensi kehadiran pegawai menggunakan arduino.dimana prototype ini dapat memudahkan dan memberikan efesiensi dalam proses absensi pegawai di setiap perkantoran, karena tidak lagi menggunakan absensi konvensional yang perlu catat mencatat.

\subsection{Absensi}

Absensi berarti "tidak hadir", namun bisa dikatakan pula absensi merupakan ketidakhadiran atau kehadiran suatu objek dalam hal ini adalah orang, dimana orang tersebut terlibat dalam suatu organisasi yang mengharuskan adanya pemberitahuan tentang keadaan atau kehadiran atau ketidakhadirannya dalam ruang lingkup organisasi tersebut (Aplikasi et al., 2021).

Absen menurut kamus besar Bahasa Indonesia merupakan tidak hadirnya seseorang dalam sebuah instansi. Sedangkan absensi biasa disebut sebagai proses penandaan atau pencatatan waktu hadir seseorang dalam sebuah dokumen yang dibuat sebagaimana mestinya guna sebagai acuan dalam menentukan sebuah keputusan dalam lingkup penilaian. Sehingga dapat disimpulkan bahwa absensi atau kartu jam hadir ialah dokumen yang mencatat jam hadir setiap siswa di sekolah. Catatan jam hadir siswa tersebut dapat berupa daftar hadir biasa, dapat juga pula berbentuk kartu hadir yang diisi dengan mesin pencatat waktu.

\subsection{Arduino Uno}

Arduino Merupakan sistem mikroprosesor lengkap yang terkandung didalam sebuah chip yang memadukan CPU, ROM, RMW, I/O paralel,I/O seri,counter timer dan rangkaian clock didalamnya. Dengan kata lain arduino adalah sebuah alat elektronika yang mempunyai masukan dan keluaran serta kendali dengan program yang bisa ditulis dan dihapus dengan cara yang tertentu (Frianto et al., 2016).

Arduino pada intinya adalah sebuah sistem mikroprosesor yang di dalamnya terdapat CPU, ROM, RAM, I/O, Clock dan peralataninternal lainya yang sudah saling terhubung dan saling terorganisasi(teralamati) dengan baik oleh pabrik pembuatanya dan dikemas dalam satu chip yang siap pakai (Fauziah et al., 2017).

Bentuk Arduino Uno dapat di lihat pada Gambar 1 di bawah ini:

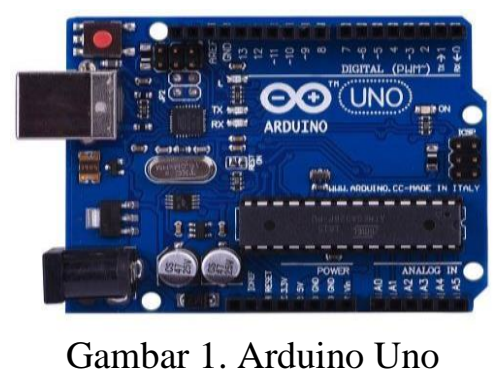

\subsection{LCD (Liquid Crystal Display)}

LCD (Liquid Crystal Display) merupakan suatu jenis media tampil yang menggunakan kristal cair sebagai penampil utama. Lcd sudah digunakan diberbagai bidang misalnya alat-alat elektronik seperti kalkulator, televisi, komputer, dan lain-lain. Lcd display ini memiliki jumlah karakter 2x16, terdiri dari 16 karaktek 12 baris (Tarmuji, 2014).

LCD dapat dilihat pada Gambar 2 berikut ini. 


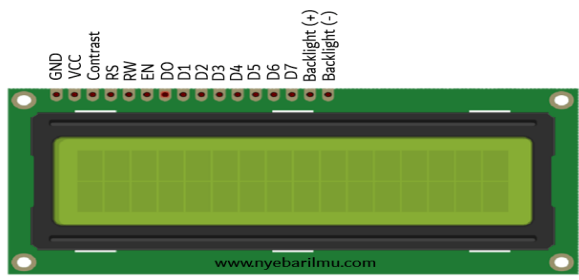

Gambar 2. Relay

\subsection{NodeMCU}

NodeMCU ESP8266merupakan chip terintegrasi yang dirancang untuk menghubungkan mikrokontroler dengan internet melalui Wi-Fi. Ia menawarkan solusi jaringanWi-Fi yang lengkap dan mandiri, yang memungkinkan untuk menjadi host ataupun sebagai Wi-Fi client (Hidayat et al., 2018).

NodeMCU adalah salah satu firmware modul ESP8266 yang bersifat opensource dan terdapat development kituntuk memudahkan membangun prototipe produk Internet of Things (IoT) dengan menggunakan bahasa pemograman (Yuliansyah, 2016).

Gambar NodeMCU dapat dilihat pada Gambar 3 berikut ini:

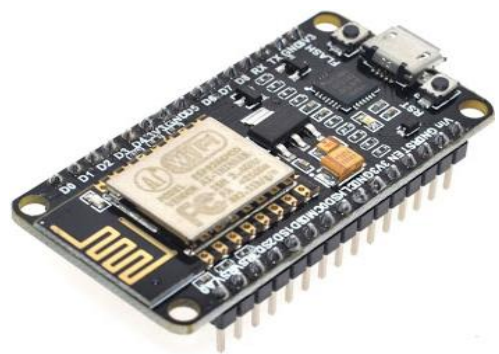

Gambar 3. NodeMCU

\subsection{Kabel Jumper}

Kabel jumper merupakan kabel dengan isi tunggal yang dipakai untuk menghubungkan antara titik satu dengan titik lainnya didalam satu projectboard (Fakhrana, 2016).

Dalam penelitian ini kabel Jumper berfungsi untuk menghubungkan beberapa alat seperti Arduino uno R3 keNodeMCU, atau menghubungkan Arduino uno R3 ke LCD dan lain-lain. kabel jumper dapat dilihat pada Gambar 4 di bawah ini:

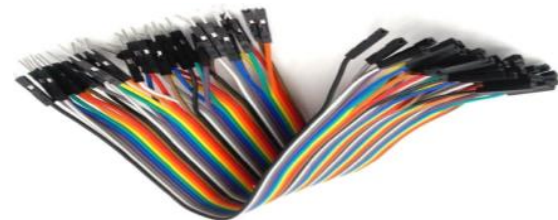

Gambar 4. Kabel Jumper

\subsection{Arduino IDE}

Arduino IDE merupakan software yang dapat digunakan untuk membuat kode program dilengkapi dengan fitur pada toolbar memiliki fungsi yang dapat membantu dalam menghubungkan program dengan mikronontroler arduino. Program yang dibuat dengan arduino IDE disebut dengan sketches. File sketches yang dibuat selanjutnya akan disimpan dengan menggunakan format .ino. Berbagai fitur yang dapat digunakan dalam membuat kode program seperti copy, paste, cut, searching dan replace text (Mikrokontroller \& Berbasis, 2016). 


\subsection{Adaptor}

Adaptor Secara umum Adaptor adalah rangkaian elektronika yang berfungsi untuk mengubah tegangan AC (arus bolak-balik) yang tinggi menjadi tegangan DC (arus searah) yang lebih rendah.

Adaptor dapat dilihat pada Gambar 5 berikut ini.

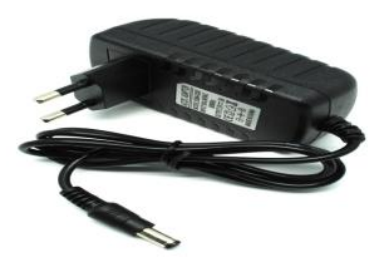

Gambar 5. Kabel Jumper

\section{METODE PENELITIAN}

Metode penelitian ini berisikan tentang bagaimana cara sistematis yang digunakan oleh para peneliti dengan tujuan mendapatkan jawaban yang tepat atas apa yang menjadi pertanyaan pada objek penelitian atau upaya untuk mengetahui sesuatu dengan rangkaian sitematis.

Penelitian yang dilakukan dimulai dengan mengidentifikasi masalah tentang absensi yang masih menggunakan absensi manual sehingga menyulitkan perekapan, dan proses input data, selain itu absensi manual membutuhkan banyak ruang penyimpanan dan banyaknya kertas yang dibutuhkan.

\subsection{Rancangan Penelitian}

Pada system Absensi otomatis menggunakan RFID dengan Arduino uni, penulis membuat beberapa tahapan perancanangannya, mulai dari pengambilan data sampai dengan pengolahan yang akan dibuat sehingga hasil outputnya lebih jelas.

Gambar Rancangan penelitian dapat dilihat ada Gambar 6 berikut ini.

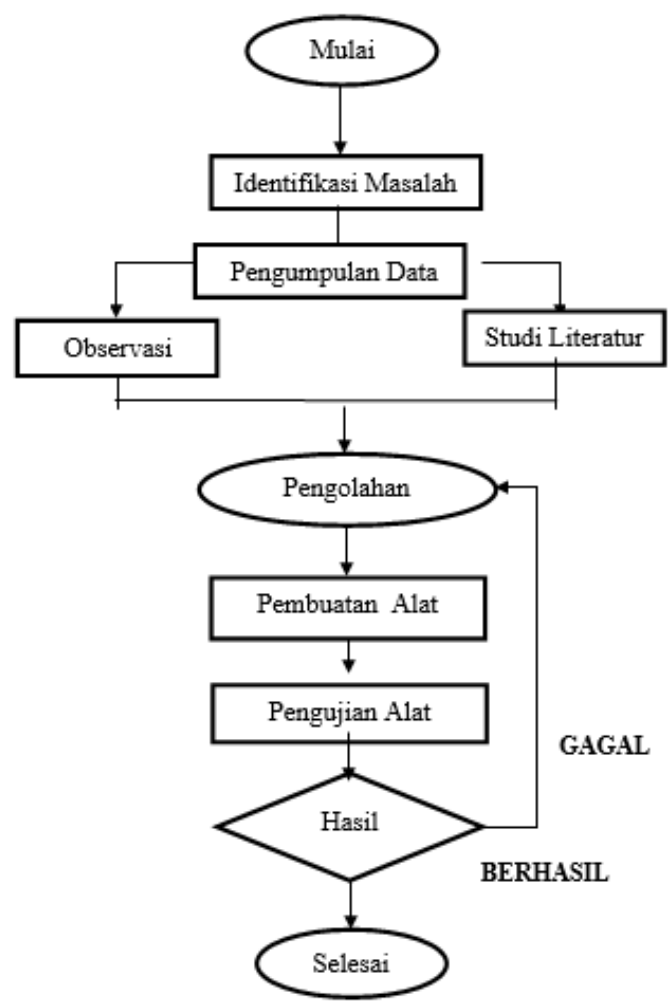

Gambar 6. Rangkaian Penelitian 
berikut:

Penjelasan Rangkaian penelitian yang di buat penulis seperti pada gambar diatas adalah sebagai

1. Identifikasi Masalah

Penelitian yang dilakukan dimulai dengan mengidentifikasi masalah tentang absensi yang masih menggunakan absensi manual sehingga menyulitkan perekapan, dan proses input data, selain itu absensi manual membutuhkan banyak ruang penyimpanan dan banyaknya kertas yang dibutuhkan.

2. Pengumpulan Data

Data pada penelitian ini diperoleh dari absensi pegawai di kantor camat kabupaten simalungun.

3. Pengolahan Data

Pada langkah ini data-data yang sudah di dapat dari studi identifikasi masalah dan pengumpulan data yang kemudian di olah untuk menyelesaikan permasalahan yang di temukan.

4. Studi Literatur

Metode pengumpulan data yang menggunakan beberapa jurnal sebagai referensi untuk penulis

5. Observasi

mengumpulkan data (observasi) di stikom tunas bangsa dan menentukan fakta-fakta dalam mempelajari kondisi yang ada di lapangan serta dalam perancangan sistem menggunakan metode beraliran data dengan menggunakan DFD (Data Flow Diagram) sebagai alat bantunya.

6. Pembuatan Alat

Selanjutnya adalah merancang sebuah alat yang dapat menyelesaikan permsalahan yang di alami.

7. Pengujian Alat

Melakukan pengujian alat menyesuaikan dengan melakukan absensi otomatis

8. Hasil

Menghasilkan alat yang di rancang dan Mengimplementasikan alat yang di buat agar dapat di gunakan.

\subsection{Perancangan Perangkat Keras}

Dalam meringankan perancangan sistem ini maka penulias akan memakai blok diagram untuk tahapan awal dalam proses pembuatannya, dimana blok diagram ini digunakan untuk menampilkan bagaimana cara kerja sistem ini dilakukan secara umum. Sistem rangkaian dapat dilihat pada gambar di bawah ini.

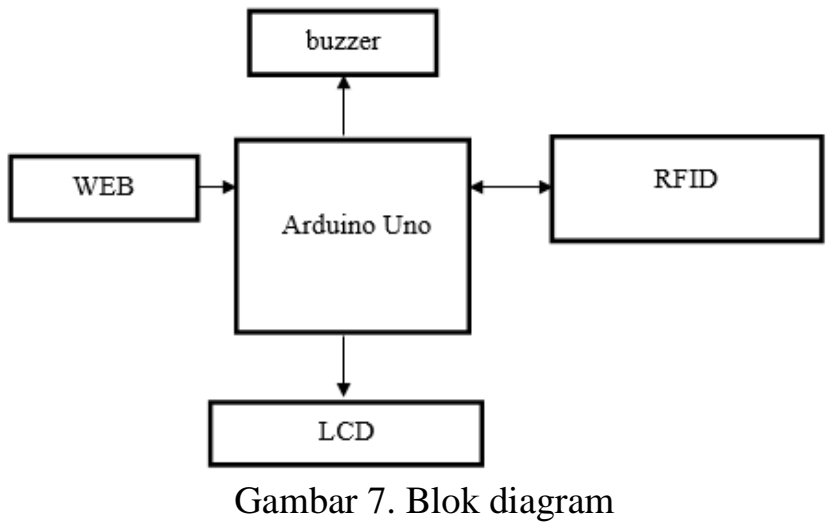

Pada Gambar diatas terdapat beberapa komponen perangkat keras system Absensi Otomatis dengan RFID, antara lain:

1. Catudaya merupakan komponen yang berfungsi untuk memberikan energi listrik ke rangkaian yang terdapat dalam sistem.

2. RFID merupakan suatu metode identifikasi objek yang menggunakaan gelombang radio

3. LCD adalah suatu jenis media tampilan yang menggunakan kristal cair sebagai penampilan utama

4. Tap kartu RFID jika kartu sudah terdaftar maka buzzer akan berbunyi 


\subsection{Cara Kerja Alat}

Prototype alat absensi otomatis ini dirancang dengan memanfaatkan teknologi Radio Frequency Identification (RFID) sebagai alat identifikasi data siswa. Untuk alur kerja yang dapat digambarkan pada control flowchart diagram diatas adalah sebagai berikut:

1. Tampilkan ID card.

2. Membaca ID card.

3. Nama pemilik akan di tampilkan di LCD.

4. Mengirim data ke web.

5. Pengiriman gagal akan di tampilkan.

6. Tampilkan nama dan data id card.

\section{HASIL DAN PEMBAHASAN}

Setelah perancangan alat selanjutnya akan menuju ke pembuatan prototype dan simulasi. Dimana sensor RFID Kartu RFID dengan frequency $145 \mathrm{Khz}$ berfungsi untuk menyimpan kode identitas pegawai Kartu RFID di tempelkan ke modul RDM6300, dimana modul ini akan membaca kode didalam kartu RFID yang akana dikirimkan ke mikrokontroller. Modul ini membaca kartu RFID yang mempunyai frequency $145 \mathrm{Khz}$.

Adapun skema rangkaian keseluruhan Alat absensi otomatis ini dirancang dengan memanfaatkan teknologi Radio Frequency Identification (RFID) dapat dilihat pada Gambar 8 di bawah ini.

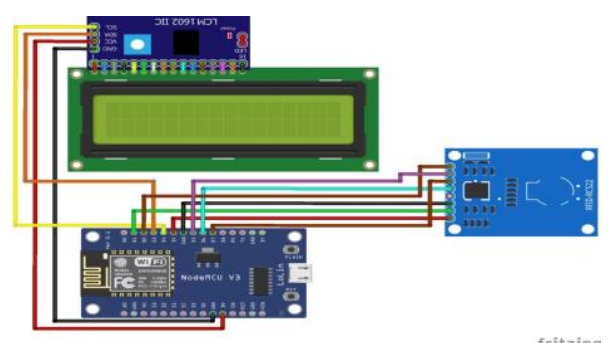

Gambar 8. Rangkaian alat

Dari skema rangkaian pada gambar diatas instalasi dan pemasangan dan beberapa komponen lainnya dengan mengkoneksikan pin di setiap modul kepin yang terdapat pada Arduino tersebut, Pin yang saling terkoneksi diatas dapat di lihat sebagai berikut:

1. Pin Vec LCD di koneksikan pada 3v NodeMCU

2. Pin Gnd LCD di koneksikan pada Gnd NodeMCU

3. Pin SCL LCD di koneksikan pada pin D4 NodeMCU

4. Pin SDA LCD di koneksikan pada pin D3 NodeMCU

5. Pin SDA RFID koneksikan pada pin D2 NodeMCU

6. Pin SCK RFID di koneksikan pada pin D5 NodeMCU

7. Pin MOSI RFID di koneksikan pada D7 NodeMCU

8. Pin MISOI di koneksikan pada pin D6 NodeMCU

9. Pin GND RFID di koneksikan pada GND NodeMCU

10. Pin RST RFID di koneksikan pada pin D1 NodeMCU

11. Pin 3.3v RFID di kokeksikan pada pin 3V NodeMCU

Setelah menyambungkan atau mengkoneksikan pin sesuai dengan skema rangkaian, selanjutnya yang di lakukan adalah mengupload program dengan menggunakan Bahasa pemrograman C++ dengan software Arduino IDE. Sehingga alat bekerja sesuai dengan yang sudah di rancang.

\subsection{Rangkaian Fisik Alat}

Rangkaian fisik Alat absensi otomatis ini dirancang dengan memanfaatkan teknologi Radio Frequency Identification (RFID) dapat dilihat pada gambar di bawah ini. 


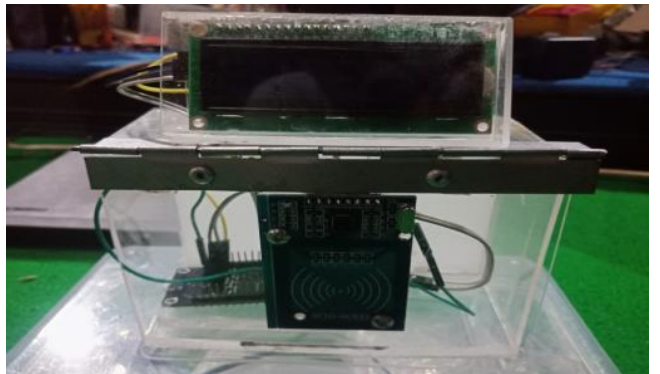

Gambar 9. Rangkaian Fisik alat

\subsection{Pengujian Alat}

Untuk melihat proses keseluruhan dari sistem absensi mulai Pengujian sistem ini dilakukan dengan menjalankan aplikasi sistem absensi Sistem absensi akan menunggu masukan dari RFID tag. Ketika RFID tag terdeteksi maka RFID reader akan mengambil data dari RFID tag kemudian mengirim data tersebut kedalam website melalui NodeMCU ESP8226 sebagai data inputan, apabila data tersebut merupakan data inputan yang dibutuhkan oleh website maka data tersebut akan tersimpan ke dalam database. Setalah dilakukan uji coba alat, alat ini berjaan dengan baik mulai dari mendeteksi RFID tag sampai dengan pemerosesan data di website.

\subsection{Web}

Website yaitu kumpulan halaman web yang saling terhubung dan file-filenya saling terkait.Web terdiri dari page atau halaman, dan kumpulan halaman yang dinamakan homepage berada pada halaman posisi teratas dengan halaman-halaman terkait berada dibawahnya. Biasanya setiap halaman dibawah homepage disebut child page, yang berisi hyperlink kehalaman lain dalam web.

Didalamnya akan terdapat informasi pengujian ini di lakukan dengan menampilkan halaman utama web absensi bisa dilihat di pada gambar berikut ini:

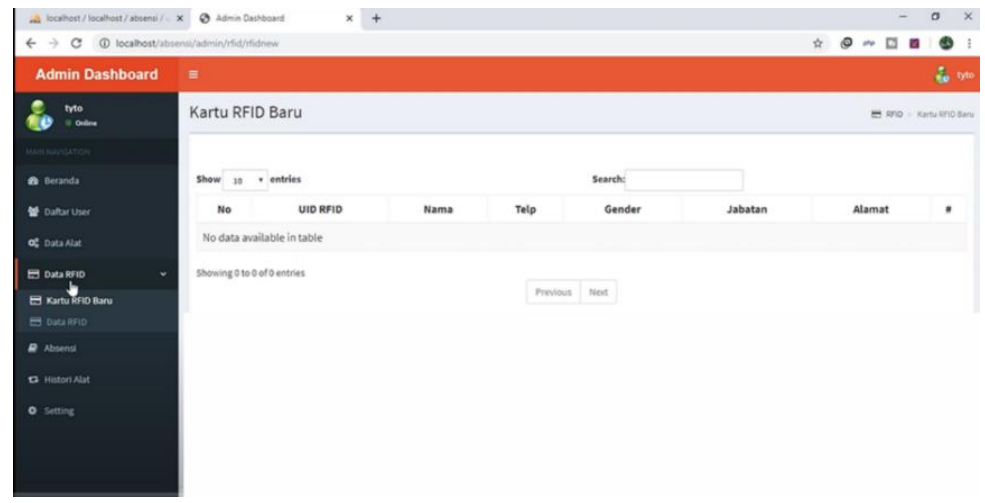

Gambar 10. Website Absensi

\subsection{Prosedur Sistem Kerja}

Dengan menggunakan alat absensi otomatis yang telah penulis rancang, validasi sistem ini bekerja saat KTP didekatkan pada RFID Reader sehungga akan terjadi proses pembacaan kode. Lalu data berupa kode tersebut nanti akan terkirim ke mikrokontroler NodeMCU. Untuk menguji alat absensi otomatis menggunakan RFID yang telah dirancang maka alat ini akan membantu dalam proses absensi.

1. Masukan (input)

Untuk memprogram mikrokontroler arduino dibutuhkan software Arduino IDE yang berbasis bahasa $\mathrm{C}++$, dan software ini membutuhkan libery untuk setiap komponen atau sensor yang akan di program guna mempermudah dalam program, terdapat softwere preocessing yang di gunakan untuk menulis program ke dalam Arduino.

2. Pemrosesan (Procces) 
Sistem diprogram pada nodemcu absensi yang diproses adalah pegawai yang mendekatkan kartu KTP dengan RFID reader dalam batas toleransi keterlambatan (15 menit). Pada saat kartu didekatkan, maka kartu akan terjadi identifikasi kartu dan terhubung ke serial port serta data akan masuk.

3. Keluaran (Output)

Selanjutnya menjalan kanperintah tag RFID yang sudah terdaftar maka secara otomatis web akan menampilkan kunjungan pada tanggal dan waktu sesuai mentag RFID atau KTP.

\section{KESIMPULAN}

Berdasarkan hasil uraian dari bab - bab sebelumnya serta hasil yang dilakukan selama melakukan penelitian dan pengujian alat absensi otomatis ini dirancang dengan memanfaatkan teknologi Radio Frequency Identification (RFID) maka dapat disumpulkan bahwasanya sistem ini berjalan dengan baik dan lancar, Dengan menggunakan sistem absensi pegawai menggunakan teknologi RFID ini, akan sangat membantu pegawai dala hal kesediplinan dan ketepan waktu dalam hal kehadiran yang telah di absen langsung dan tersimpan kedalam database di komputer server.

Pengelolaan data hasil yang telah di input, dan arsip laporan yang sering terjadinya kehilagan berkas sudah tidak terjadi lagi karena sudah tersimpan di database. Dengan sistem absensi pegawai menggunakan teknologi $R F I D$, dapat mempercepat proses absensi kepegawaian yang sebelumnya masih harus mengisi from dengan tanda tangan.

\section{DAFTAR PUSTAKA}

Aplikasi, P., Meet, G., Media, U., \& Dimasa, P. (2021). Jurnal ABDIMAS Budi Darma. 2(1), 83-86.

Fakhrana, A. (2016). Pembuatan prototype robot kapal pemungut sampah menggunakan mikrokontroler arduino uno dengan aplikasi pengendali berbasis android. Jurnal Ilmiah Teknologi Dan Rekayasa, 21(3), 185-195.gut sampah m. Jurnal Ilmiah Teknologi Dan Rekayasa, 21(3), 185-195. https://ejournal.gunadarma.ac.id/index.php/tekno/article/view/1597/1356

Fauziah, H. Y., Sukowati, A. I., \& Purwanto, I. (2017). Rancang Bangun Sistem Absensi Mahasiswa Sekolah Tinggi Teknik Cendekia (STTC) Berbasis Radio Frequency Identification (RFID) menggunakan Arduino UNO R3. Jurnal Ilmiah Komputasi, 16(2), 1-2. https://doi.org/10.32409/jikstik.16.2.2288

Frianto, H. T., Anwar, Salman, A., Hasman, J., Lubis, R., Nasruddin, Murtopo, \& Gunawan. (2016). Absensi Mahasiswa Menggunakan Sensor RFID Untuk Perhitungan Kompensasi Kehadiran. Jurnal Riset Komputer (JURIKOM), 3(1), 113-116.

Hidayat, M. R., Christiono, C., \& Sapudin, B. S. (2018). PERANCANGAN SISTEM KEAMANAN RUMAH BERBASIS IoT DENGAN NodeMCU ESP8266 MENGGUNAKAN SENSOR PIR HC-SR501 DAN SENSOR SMOKE DETECTOR. Kilat, 7(2), 139-148. https://doi.org/10.33322/kilat.v7i2.357

Mikrokontroller, M., \& Berbasis, D. A. N. (2016). No Title. 12.

Mutu, M., Air, K., \& Sekolah, D. I. (2019). Corresponding Author Email : 3(1).

Tarmuji. (2014). Perancangan dan pembuatan alat pengukur getaran mekanis menggunakan piezzo electric sensor berbasis arduino mikrokontroller. Emitor, 15(02), 53-59.

Yuliansyah, H. (2016). Uji Kinerja Pengiriman Data Secara Wireless Menggunakan Modul ESP8266 Berbasis Rest Architecture. Jurnal Rekayasa Dan Teknologi Elektro, 10(2 (Mei 2016)), 68-77. 